\title{
Morphoanatomy and histochemistry analyses of cassava roots do not discriminate resistant from susceptible genotypes to soft root rot
}

\author{
Jonny Lucio Sousa SILVA ${ }^{1}$, Elisa Ferreira MOURA ${ }^{2}$, Fernanda ILKIU-BORGES ${ }^{2}$, \\ Jessivaldo Rodrigues GALVÃO ${ }^{1}$, João Tomé de FARIAS-NETO², Gisele Barata da SILVA ${ }^{1}$, \\ Marcela Cristiane Ferreira RÊGO ${ }^{1}$, Roberto Lisboa CUNHA ${ }^{2}$ \\ 1 Universidade Federal Rural da Amazônia, Belém, Pará, Brazil \\ 2 Embrapa Amazônia Oriental, Belém, Pará, Brazil \\ *Corresponding author: elisa.moura@embrapa.br
}

\section{ABSTRACT}

Cassava is an important culture in Brazil and in the North of the country, and soft root rot has affected root production. The aim of this work was to identify root morphoanatomic and histochemical characters associated with root rot resistance. In areas with no occurrence of the disease, nine cassava genotypes were tested, four of which were resistant, and five were susceptible to root rot. Root harvest was carried out twelve months after sowing, and thickness of suber, suber and cortex, and secondary xylem were measured. Moreover, texture, suber cell layers, lignin content, and lignin monomers content of the portion suber and cortex were analyzed. Also, histochemical tests and scanning electron microscopy (SEM) analyses of the roots were performed. Results were subjected to analysis of variance, and means were compared by the Scott-Knott test $(\mathrm{p} \leq 0.05)$. The characters thickness of suber and cortex at proximal and medium portions, thickness of secondary xylem at medium and apical portions, number of cell layers of suber, thickness of suber, and root texture showed differences among genotypes; however, the characters could not be associated with resistance or susceptibility. There were no differences for: vessel elements, lignin and lignin monomers, and for the histochemical tests with Sudan IV and Lugol. Images of SEM showed differences among genotypes, which could not be associated with resistance or susceptibility. Thus, the characters evaluated cannot be used in selection for cassava resistance to soft root rot in genetic breeding programs.

KEYWORDS: Anatomy; morphological characterization; genetic breeding; Manihot esculenta

\section{Morfoanatomia e histoquímica de raízes de mandioca não diferenciam genótipos resistentes e suscetíveis a podridão mole da raiz}

\section{RESUMO}

A mandioca é uma cultura importante no Brasil e no Norte do país, e a podridão mole da raiz tem afetado a produção. O objetivo deste trabalho foi identificar caracteres morfoanatômicos e histoquímicos da raiz associados à resistência à podridão da raiz. Em áreas sem ocorrência da doença, nove genótipos de mandioca foram testados, quatro resistentes e cinco suscetíveis. A colheita da raiz foi realizada doze meses após o plantio e medidas de espessura do súber, súber e cortex e xilema secundário foram realizadas. Além disso, foram analisados a textura, as camadas de célula do súber, o conteúdo de lignina e os monômeros de lignina da porção súber e cortex. Ainda, testes histoquímicos e microscopia eletrônica de varredura (MEV) das raízes foram realizados. Os resultados foram submetidos à análise de variância e as médias foram comparadas pelo teste de Scott-Knott $(\mathrm{p} \leq 0.05)$. Os caracteres: espessura de súber e córtex nas porçóes mediana e proximal, espessura do xilema secundário nas porçóes mediana e apical, número de camadas de células do súber, espessura do súber e textura da raiz apresentaram diferenças entre os genótipos, mas não associadas à resistência ou suscetibilidade. Não houve diferenças para: elementos de vaso, lignina e monômeros de lignina para os testes histoquímicos com Sudan IV e Lugol. Imagens de MEV apresentaram diferenças entre os genótipos, mas não associadas à resistência ou suscetibilidade. Assim, os caracteres avaliados náo podem ser usados na seleçáo de mandioca com resistência à podridão mole da raiz em programa de melhoramento genético.

PALAVRAS-CHAVE: anatomia; caracterização morfológica; melhoramento genético; Manihot esculenta 


\section{INTRODUCTION}

In Brazil, cassava (Manihot esculenta Crantz) has a nutritional, economic and social importance. According to the Brazilian Institute of Geography and Statistics (IBGE 2015), Brazilian production reached 22.8 million tons of roots in 2015 , which represents a decrease of $3.7 \%$, when compared with 2014, when 22.7 million tons were produced. Nowadays, Nigeria is the main world producer, while Brazil occupies the fourth position. The State of Pará produced 20.6\% of total Brazilian production of cassava roots (IBGE 2015).

Moreover, diseases incidence can drastically reduce root production. Root rots are one of the most important diseases, and they are a limiting factor for production increase and culture expansion in some Brazilian regions (Muniz et al. 2006). Soft root rot is a type of root rot in which roots acquire an aqueous aspect. Humid tropics are the regions where cassava roots are the most affected by root rots, since humidity and high rainfall incidence facilitate life cycles of pathogens. In the State of Pará, soft root rot is mainly caused by Phytophthora spp. and Pythium spp. (Figueiredo and Albuquerque 1970; Poltronieri et al. 1997).

Higher yields, starch content, and lower moisture can be obtained when roots are harvested after a year of planting, which is also dependent on the cassava genotype (Mendonça et al. 2003). However, since soft root rot is associated with rainy periods and poorly drained soils, farmers tend to anticipate harvest, which results in yield decrease per planted area. In face of these phytosanitary issues and of the use of agricultural defensives, selection of resistant or susceptible genotypes to soft root rot is an alternative to control the disease.

Cassava resistance to soft root rot seems to have multigenic control (Alvarez et al. 2002). Multigenic control may be associated with morphological and anatomical characters of the plant. Román-Avilles et al. (2004) have identified that resistance of common bean to root rot was associated with higher production of adventitious roots. Higginbotham et al. (2004) also identified that morphological modifications of wheat plants were associated with resistance to root rot caused by Pythium spp. The possibility of selecting tolerance to a disease based on morphological characters of simple measurement represents gain for genetic breeding, since it saves time and money in the selection process. The aim of this work was to verify if there are morphoanatomical characters of cassava root associated with resistance or susceptibility of genotypes to soft root rot.

\section{MATERIALS AND METHODS}

Nine cassava genotypes resistant or susceptible to soft root rot, of the Active Germplasm Bank (AGB) of Brazilian Agricultural Research Corporation (Embrapa) Eastern
Amazon were evaluated. The four genotypes resistant and recommended for planting were: BRS Kiriris, BRS Poti, BRS Mari and CPATU 193, and the five susceptible were: CPATU 285, CPATU 470, CPATU 489, CPATU 302 and CPATU 530. The accession CPATU 193 is under evaluation trials, and is tolerant to soft root rot in the field. This genotype was used only in scanning electron microscopy analyses.

Genotypes were grown in the municipality of Igarapé-Açu, State of Pará $\left(01^{\circ} 11^{\prime} S ; 47^{\circ} 35^{\prime} \mathrm{W}\right)$. The average rainfall per year is $2350 \mathrm{~mm}$, and the average temperature is $25^{\circ} \mathrm{C}$ (IDESP 2014). A trial was established in an area with no history of the disease. The planting trial was carried out on a $1.0 \mathrm{~m} \mathrm{x}$ $1.0 \mathrm{~m}$ spacing, with tillage and plowing for soil preparation, and only one fertilizer application with nitrogen, phosphorous and potassium (10-28-20 formula), at 35 days after planting the stakes, when $40 \mathrm{~g}$ fertilizer were used per planting hole. No irrigation was performed. Roots were harvested 12 months after planting.

The texture of in natura peel samples were analyzed. Measurements were carried out using a texture analyzer (TA. XT 2, Texture Technologies, Hamilton, EUA), previously calibrated according to the manufacturer's norms. Texture was measured in three points of the root (apical, medium and basal), using three roots per plant from three plants for each one of the eight genotypes. These measurements were carried out in the superficial portion of the root, with approximately $5.0 \mathrm{~mm}$ depth. Measures were presented in unities of Newton $(\mathrm{N})$.

Soon after harvest, it was measured the portions of the root in cross-section of AV1, AV2 and AV3, in three parts of the root: apical, medium and basal, with the aid of a caliper rule. Three roots from three plants of each genotype were measured, totaling 27 measures per genotype.

The anatomical analyses were evaluated from the limits of root fractions in: AV1 (suber evaluation), AV2 (phellogen, phelloderm, pericycle, primary phloem, secondary phloem and vascular cambium), and AV3 (secondary xylem) (Figure 1).

For anatomical and histochemical analyses of the roots, samples of the medium portion, and containing the periderm and cortex, were fixed in FAA $50(50 \mathrm{~mL} 37 \%$ formaldehyde, $50 \mathrm{~mL}$ glacial acetic acid, and $900 \mathrm{~mL} 50 \%$ ethanol). Two days later, the fixative was discarded, and the portions of the roots were stored in $70 \%$ ethanol until further processing. Free-hand cross-sections of roots were obtained for each genotype at radial planes. The sections were cleared in $2 \%$ sodium hypochlorite $(\mathrm{NaClO})$ for 1 minute, placed in $1 \%$ astrablau for 30 seconds, and then placed in 1\% basic fuchsin. Measurements of eight free-hand cross-sections per repetition and per genotype using a millimetric eyepiece on a Motic BA-400 microscope were carried out in ten randomly chosen 


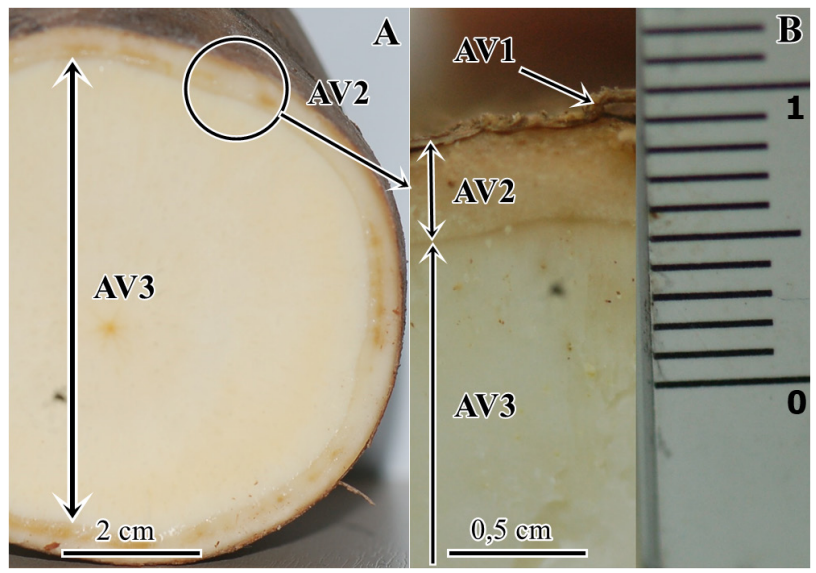

Figure 1. Cross-section of cassava root (Manihot esculenta) of the cultivar BRS Kiriris, demonstrating the three portions studied, in which: AV1 represents the suber; AV2 represents the phellogen, the phelloderm, the pericycle, the primary phloem, the secondary phloem, and the vascular cambium; and AV3 represents the secondary xylem. This figure is in color in the electronic version.

sites. The parameters evaluated were: thickness and number of layers in the suber.

For suber measurement (AV1) and AV1 cell layer counting, semi-permanent slides were prepared with cross-sections stained with basic fuchsin and astra blue and mounted with $5 \%$ glycerine. The sections were analyzed in light microscope (BX60M, Olympus, Napoli, Italia).

For scanning electron microscopy (SEM), root samples of approximately $1 \mathrm{~cm}^{3}$ previously fixed in FAA and stored in ethanol were subjected to dehydration process in a graded ethanol series (30, 50, 70, 80, 90, 95 e 100\%) for 2 hours and 20 minutes, 20 minutes in each step. Subsequently, samples were subjected to critical point drying and sputter-coating with gold. Samples were analyzed in a scanning electron microscope (JMS-5400 LV, JEOL, Massachusetts, EUA), at the Laboratory of Geology of Emilio Goeldi Museum, in Belém, Pará (BX60M, Olympus, Napoli, Italy) with a camera to capture images.

Histochemical tests and scanning electron microscopy were carried out for qualitative evaluations. Histochemical tests were performed on free-hand cross-sections of the roots. For lipids identification, it was used $1 \%$ Sudan IV for 30 minutes, followed by washing in 30\% ethanol (Johansen 1940). For starch grains identification, it was used $1 \%$ reagent of Lugol solution for five seconds (Berlyn and Miksche 1976), and afterwards, they were visualized in an optical microscope with a digital camera (BX60M, Olympus, Napoli, Italia).

For the measurement of vessels, pits and fibers, some samples of the $\mathrm{AV} 3$ portion were removed and dried in a stove at $65^{\circ} \mathrm{C}$ for $24 \mathrm{~h}$ in $50 \%$ glacial acetic acid: $38 \%$ hydrogen peroxide - $130 \mathrm{~V}: 12 \%$ distilled water. Then, samples were washed with water and macerated (Berlyn and Miksche 1976). The dissociated material was stained with $1 \%$ safranin in $50 \%$ ethanol (Kraus and Arduin 1997).

In order to quantify lignin and lignin monomers, both periderm and cortex were removed from three roots of each one of the eight genotypes. Samples were homogenized in $50 \mathrm{mM}$ sodium phosphate buffer, with $\mathrm{pH} 7.0$, purified in $1 \%$ Triton $\mathrm{X}-100,1 \mathrm{M} \mathrm{NaCl}$, and acetone, and centrifuged for 15 minutes. Lignin was quantified using the thioglycolic acid method (Kováćik and Klejdus 2008), and lignin monomers were quantified using alkaline nitrobenzene peroxidation (Van Der Rest et. al 2006).

Analyses considered genotypes as treatments, each one with three replicates. Three roots of one plant represented each replicate. Analysis of variance was applied to the characters evaluated, and in case of significance at 1 or 5\%, Scott-Knott test was applied to categorize means. Analyses were carried out using the Sisvar 5.1 software (Ferreira 2011).

\section{RESULTS}

Table 1 shows the results of the analysis of variance of the morphoanatomical characters. There were significant differences among the genotypes regarding the measurement of $\mathrm{AV} 2$ at the proximal and medium portions; the measurement of AV3 at medium and apical portions; the number of AV1 cell layers; the root texture; and the AV1 thickness. Coefficients of variation ranged from $34.12 \%$ for the measurement of lignin to $13.51 \%$ for root texture (Table 1 ).

The mean thickness of the medium section was higher than that of the apical and proximal sections (Table 1). This pattern was the same for all genotypes.

The mean of AV2 thickness at the proximal portion for resistant genotypes ranged from $0.29 \mathrm{~cm}$ (BRS Kiriris) to 0.23 $\mathrm{cm}$ (BRS Poti); and for susceptible genotypes, it ranged from $0.34 \mathrm{~cm}$ (CPATU 285) to $0.21 \mathrm{~cm}$ (CPATU 489). The means of AV2 thickness at medium portion for resistant genotypes ranged from $0.32 \mathrm{~cm}$ (BRS Kiriris) to $0.24 \mathrm{~cm}$ (BRS Mari) (Table 1); and for susceptible genotypes, it ranged from 0.36 cm (CPATU 285) to $0.26 \mathrm{~cm}$ (CPATU 470) (Table 1).

The means of AV3 thickness at medium portion for resistant genotypes ranged from $5.97 \mathrm{~cm}$ (BRS Kiriris) to 4.82 $\mathrm{cm}$ (BRS Mari) (Table 1); and for susceptible genotypes, it ranged from $4.54 \mathrm{~cm}$ (CPATU 285) to $5.52 \mathrm{~cm}$ (CPATU 470) (Table 1). The means of AV3 thickness at apical portion for resistant genotypes ranged from $3.6 \mathrm{~cm}$ (BRS Poti) to $2.98 \mathrm{~cm}$ (BRS Kiriris); and for susceptible genotypes, it ranged from 4.52 (CPATU 530) to $2.76 \mathrm{~cm}$ (CPATU 470).

The means of number of cell layers for resistant genotypes ranged from 31 (BRS Kiriris) to 21 (BRS Mari); and for 
Table 1. Summary of the analysis of variance and Scott-Knott test of morphoanatomic characters: AV2 (measured in $\mathrm{cm}$ ) for the proximal (PR0), medium (MED) and apical (API) portions; AV3 thickness (measured in $\mathrm{cm}$ ) in the proximal (PRO), medium (MED) and apical (API) portions; number of cell layers of AV1 (N.C.L).); root texture (R.TEX) (measured in Newton); AV1 thickness (T.V1) (measured in $\mu$ m); lignin (LIG) and lignin monomers (LIG.M); vessel size (V.S.) (measured in $\mu \mathrm{m}$ ); vessel width (V.W.) (measured in $\mu \mathrm{m}$ ). Measures for eight cassava genotypes (Manihot esculenta), three resistant and five susceptible to soft rot root, in the northeast of Pará conditions * F test significant at $5 \%$. ${ }^{*}$ significant at $1 \%$, by the Scott-Knott test.

\begin{tabular}{|c|c|c|c|c|c|c|c|c|c|c|c|c|c|}
\hline \multirow{2}{*}{ Genotypes } & \multicolumn{3}{|c|}{ AV2 } & \multicolumn{3}{|c|}{ AV3 } & \multirow{2}{*}{ N.C.L } & \multirow{2}{*}{ R.TEX } & \multirow{2}{*}{ T.AV1 } & \multirow{2}{*}{ LIG } & \multirow{2}{*}{ LIG.M } & \multirow{2}{*}{ V.S. } & \multirow{2}{*}{ V.W } \\
\hline & PRO & MED & API & PRO & MED & API & & & & & & & \\
\hline BRS Poti & $0.23^{c}$ & $0.25^{b}$ & 0.2 & 4.85 & $4.92^{b}$ & $3.6^{\mathrm{b}}$ & $28^{b}$ & $23.6^{a}$ & $334^{c}$ & 0.1 & 0.164 & 438 & 66 \\
\hline BRS Mari & $0.24^{c}$ & $0.24^{b}$ & 0.2 & 4.6 & $4.82^{b}$ & $3.48^{b}$ & $21^{c}$ & $20^{b}$ & $248^{d}$ & 0.05 & 0.142 & 462 & 109 \\
\hline BRS Kiriris & $0.29^{b}$ & $0.32^{\mathrm{a}}$ & 0.25 & 4.83 & $5.97^{a}$ & $2.98^{b}$ & $31^{b}$ & $19.2^{\mathrm{c}}$ & $402^{b}$ & 0.08 & 0.14 & 476 & 90 \\
\hline CPATU 285 & $0.34^{a}$ & $0.36^{\mathrm{a}}$ & 0.28 & 4.67 & $4.54^{b}$ & $3.14^{b}$ & $29^{b}$ & $18.7^{c}$ & $336^{c}$ & 0.05 & 0.123 & 496 & 103 \\
\hline CPATU 489 & $0.21^{c}$ & $0.26^{b}$ & 0.22 & 4.87 & $4.78^{b}$ & $3.31^{b}$ & $35^{\mathrm{a}}$ & $15.4^{\mathrm{d}}$ & $435^{b}$ & 0.12 & 0.18 & 493 & 62 \\
\hline CPATU 302 & $0.26^{c}$ & $0.27^{\mathrm{b}}$ & 0.24 & 4.73 & $4.91^{b}$ & $3.54^{b}$ & $20^{c}$ & $16.8^{d}$ & $251^{d}$ & 0.13 & 0.17 & 476 & 88 \\
\hline CPATU 530 & $0.24^{c}$ & $0.23^{b}$ & 0.23 & 4.38 & $5.23^{b}$ & $4.52^{\mathrm{a}}$ & $40^{\mathrm{a}}$ & $22.1^{\mathrm{a}}$ & $513^{a}$ & 0.1 & 0.142 & 488 & 81 \\
\hline CPATU 470 & $0.28^{b}$ & $0.26^{b}$ & 0.25 & 3.83 & $5.52^{\mathrm{a}}$ & $2.76^{b}$ & $18^{c}$ & $20.5^{b}$ & $226^{d}$ & 0.1 & 0.153 & 450 & 81 \\
\hline CV \% & 22.8 & 21.2 & 20.6 & 27.5 & 18.16 & 26.7 & 19.2 & 13.5 & 22.28 & 34.1 & 14.07 & 23.02 & 41.6 \\
\hline Teste F & ** & ** & ns & ns & * & ** & ** & ** & ** & ns & ns & ns & ns \\
\hline
\end{tabular}

susceptible genotypes, it ranged from 40 (CPATU 530) to 18 (CPATU 470). The means of root textures for resistant genotypes ranged from $23.6 \mathrm{~N}$ (BRS Poti) to $19.2 \mathrm{~N}$ (BRS Kiriris); and for susceptible genotypes, it ranged from $22.1 \mathrm{~N}$ (CPATU 530) to $15.4 \mathrm{~N}$ (CPATU 489). Finally, the means of AV1 thickness for resistant genotypes ranged from $402 \mathrm{~mm}$ (BRS Kiriris) to $248 \mathrm{~mm}$ (BRS Mari); and for susceptible genotypes, it ranged from $513 \mathrm{~mm}$ (CPATU 530) to 226 mm (CPATU 470).

The number of cell layers of the AV1 was correlated with AV2 thickness, which means that the higher the number of cell layers, the thicker is the AV2 (Table 2).

Results were not significant for vessel elements data (size and thickness of AV3 vessels thickness, size and type of pits), based on the analysis of variance (Table 1). Figure 2 shows images of vessel elements for resistant and susceptible genotypes. Similar results were observed for the quantification of lignin and lignin monomers, since there was no statistical difference among genotypes for these characters (Table 1).

In the nine genotypes, suber was stratified or fractioned in some sites, with 10 to 73 layers of phellem with tabular cells. The cortex presented up to three layers of big and isodiametric to oblong shaped parenchymatic cells.

According to the results of SEM, the AV1 was apparently thicker for resistant genotypes than for susceptible genotypes, with few areas of peeling cells on their surfaces (Figure 3A, B and $\mathrm{C}$ ). On the other hand, resistant genotypes showed higher

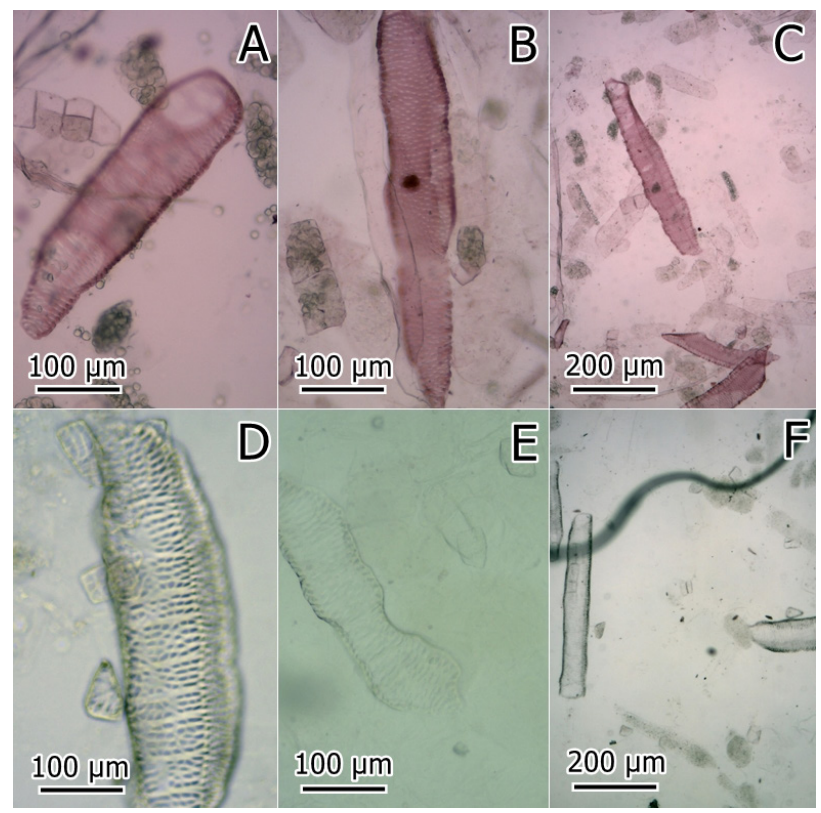

Figure 2. Light micrographs of dissociated material of secondary xylem of cassava roots (Manihot esculenta) stained with safranin. A: BRS Kiriris, resistant to soft root rot; B-C: BRS Poti, resistant to soft root rot; E-F: CPATU 530 , susceptible to soft root rot. This figure is in color in the electronic version.

deposition of dead cells on the peel surface. When resistant materials were compared, the same pattern of deposition of dead cells and AV1 thickness was observed. 
Table 2. Correlation between morphoanatomical characters of cassava root (Manihot esculenta), susceptible and resistant to soft root rot. ** significant at $1 \%$ probability level $(p<.01)$; ns not significant $(p>0.05)$.

\begin{tabular}{|c|c|c|}
\hline \multicolumn{3}{|l|}{ Correlation table } \\
\hline Correlation & Correlation Coeff. (r) & Significance \\
\hline AV2 X AV3 & 0.4664 & ** \\
\hline AV2 X R.Tex & 0.1553 & ns \\
\hline AV2 X N.C.L. & -0.0868 & ns \\
\hline AV2 X T.AV1 & -0.0491 & ns \\
\hline AV3 X R.Tex & 0.0475 & ns \\
\hline AV3 X N.C.L. & -0.152 & ns \\
\hline AV3 X T.AV1 & -0.1375 & ns \\
\hline R.Tex X N.C.L. & -0.1926 & ns \\
\hline R.Tex X T.AV1 & -0.2068 & ns \\
\hline N.C.L. X T.AV1 & 0.9276 & ** \\
\hline
\end{tabular}

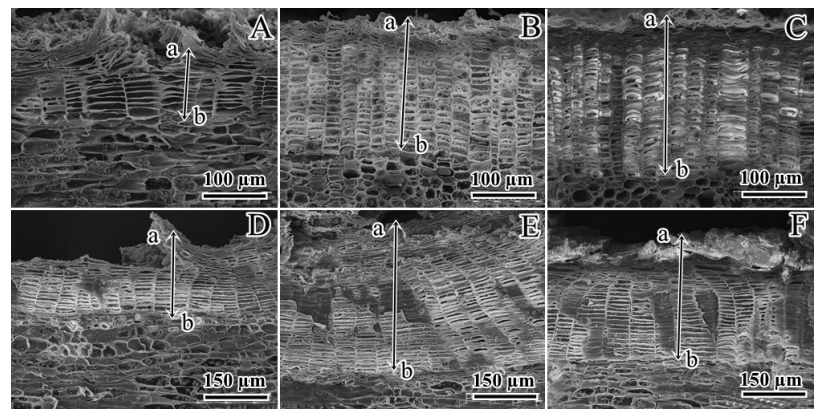

Figure 3. Cross-sections of cassava roots (Manihot esculenta) harvested after 12 months of planting, observed in a scanning electron microscope of susceptible and resistant genotypes to soft root rot. Susceptible: CPATU 302 (A), CPATU 470 (B), and CPATU 489 (C); resistant: BRS Mari (D), CPATU 193 (E), and BRS Kiriris (F). a =deposition of lignified dead cells; $b=$ cork cambium.

Histochemical test for starch grains showed no detectable difference among genotypes. Sudan IV test for lipids showed slight differences in the staining of genotypes, suggesting more deposition of lipids in the AV1. However, histochemical differences between genotypes were not observed (Figure 4).

\section{DISCUSSION}

Current results indicate that there was no relationship between the root characters measured and the characteristics of resistance or susceptibility to soft root rot. There was no relationship between AV2 thickness macroscopically measured and the root texture with resistance to root rot, since both resistant and susceptible genotypes presented high values for these characters (Table 1). There was no difference in the thickness of root peel among resistant and susceptible

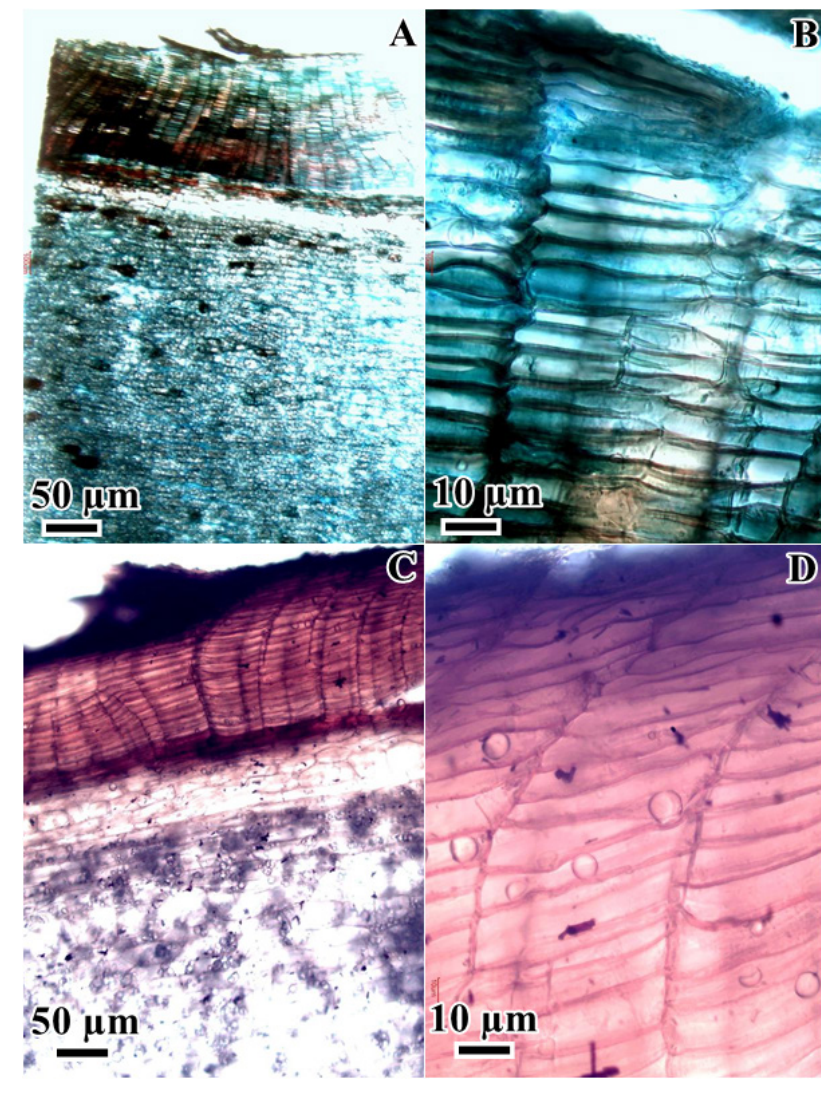

Figure 4. Light micrographs of cross-sections of cassava roots (Manihot esculenta) stained with basic fuchsin and astra blue, of the genotype CPATU 530 ( $A$ and $B$ ), and with Sudan IV, of the genotype BRS Kiriris ( $C$ and D). The tests were carried out on fresh sections of the root. This figure is in color in the electronic version.

genotypes, nor in the number of cells, since the range of values was similar for both groups (Table 1).

Lignin accumulation is associated with groups of dead cells, and can act as a barrier to water and pathogen penetration (Thomas et al. 2007; Ranathunge et al. 2008). It was observed that rice plants, when faced with a biotic stimulus, such as inoculation of fungi isolate, had higher deposition of lignin in their roots, which varied according to the fungi isolate (Rêgo et al. 2014). Thus, cassava genotypes with this characteristic may be more adapted to poorly drained soils, preventing root rot. Lignin content and lignin monomers content showed no differences among resistant and susceptible genotypes. However, these results could be the effect of using $\mathrm{AV} 2$ portions to measure these parameters.

Perhaps, the use of samples containing only AV1 can lead to the identification of differences in lignin content and lignin monomers content; thus, further analyses with the same genotypes are necessary. 
Oomicetes of the genus Phytophthora are flagellate and need water to move (Fry and Grünwald 2010). Perhaps, some lipidic components in the AV1 of the root reduces the water permeability, and therefore, affects Phytophthora infection. It is important to notice that roots were collected from a site with no occurrence of soft root rot. Thus, differences in the composition of roots among genotypes may be constitutive.

Studies have reported that preformed suberin, a compound derivative from fatty acids, and which are commonly involved in basal resistance, was higher in whole roots of a soybean genotype resistant to root rot caused by Phytophthora sojae (Thomas et al. 2007; Ranathunge et al. 2008). Thus, more detailed analyses are required to study the composition of the AV1 of roots of resistant and susceptible cassava genotypes.

This work did not find relationships between morphological characters of the root with resistance or susceptibility to soft root rot. Even though, four genetically different resistant genotypes were used, and they will guide further studies to identify characters associated with soft root rot resistance.

\section{CONCLUSION}

It is not possible to associate morphological characters of cassava root to resistance or susceptibility to soft root rot. However, more detailed biochemical analysis of the root may indicate associations with resistance.

\section{ACKNOWLEDGMENTS}

The authors thank the National Council of Technological and Scientific Development (CNPq, process 477237/2010-0), and the Brazilian Agricultural Research Corporation (Embrapa, project 0106010071409) for financial support and scholarship grants.

\section{REFERENCES}

Alvarez, E.; Loke, J.; Rivera, S.; Llano, G. 2002. Genética de la resistência a pudrición causada por phytophthora tropicalis em dos poblaciones segregantes de yuca (Manihot esculenta Crantz). Fitopatologia Colombiana, 26: 61-66.

Berlyn, G.P.; Miksche, J.P. 1976. Botanical microtechnique and cytochemistry. State University, Iowa, 326p.

Ferreira, D.F. 2011. Sisvar: A computer statistical analysis system. Ciência e Agrotecnogia, 35: 1039-1074.

Figueiredo, M.M.; Albuquerque, F.C. 1970. Podridão mole das raízes da mandioca (Manihot esculenta). Pesquisa Agropecuária Brasileira, 5: 389-393.

Fry, W.E.; Grünwald N.J. 2010. Introduction to Oomycetes. The Plant Health Instructor. DOI:10.1094/PHI-I-2010-1207-01.

Higginbotham, R.W.; Paulitz, T.C.; Campbell, K.G.; Kidwell, K.K. 2004. Evaluation of adapted wheat cultivars for tolerance to Pythium root rot. Plant Disease, 88: 1027-1032.
IDESP (Instituto de Desenvolvimento Econômico, Social e Ambiental do Pará), 2014. Estatística municipal: Igarapé Açu, 47p. (http://www.idesp.pa.gov.br/pdf/estatisticaMunicipal/pdf/ IgarapeAcu.pdf). Accessed on 29/04/2015.

Instituto Brasileiro de Geografia e Estatística - IBGE. 2015. Levantamento sistemático da produção agrícola. (http://www. ibge.gov.br). Accessed on 17/05/2016.

Johansen, D.A. 1940. Plant microtechnique. McGraw Hill, New York, 523 p.

Kováčik, J.; Klejdus, B. 2008. Dynamics of phenolic acids and lignin accumulation in metal-treated Matricaria chamomilla roots. Plant Cell Reports, 27: 605-615.

Kraus, J.E.; Arduin, M. 1997. Manual básico de métodos em morfologia vegetal. 1st ed. Seropédica: Editora da Universidade Rural, Rio de Janeiro, 198p.

Mendonça, A.H.; Moura, G.M.; Cunha, T.C. 2003. Avaliação de cultivares de mandioca em diferentes épocas de colheita, no Estado do Acre. Pesquisa Agropecuária Brasileira, 38:761-769.

Muniz, M.F.S., Andrade, F.W.R.; Queiroz, F.M.; Moura Filho, G.; Menezes, M. 2006. Caracterização de isolados de Phytophthora drechsleri, agente causal da podridão mole de raízes de mandioca. Fitopatologia Brasileira, 31: 195-198.

Poltronieri, L.S.; Trindade, D.R.; Silva, H.M.; Albuquerque, F.C. 1997. Patógenos associados à podridão mole de raízes de mandioca no estado do Pará. Fitopatologia Brasileira, 22: 111-111.

Ranathunge, K.; Thomas, R.H.; Fang, X.; Peterson, C.A.; Gijzen, M.; Bernards, M.A. 2008. Soybean root suberin and partial resistance to root rot caused by Phytophthora sojae. Phytopathology, 98: 1179-1189.

Rêgo, M.C.F.; Borges, I.B.; Filippi, M.C.C; Gonçalves, L.A; Silva, G.B. 2014. Morphoanatomical and biochemical changes in the roots of rice plants induced by plant growth-promoting microorganisms. Journal of Botany, 2014: ID 818797.

Román-Avilés, B.; Snapp, S.S.; Kelly, J.D. 2004. Assessing root traits associated with root rot resistance in common bean. Field Crops Research, 86: 147-156.

Thomas, R.; Fang, X.; Ranathunge, K.; Anderson, T.R; Peterson, C.A.; Bernardes, M.A. 2007. Soybean root suberin: anatomical distribution, chemical composition and relationship to partial resistance to Phytophthora sojae. Plant Physiology, 144:299-311.

Van Der Rest B.; Danoun, S.; Boudet, A.M.; Rochange, S.F. 2006. Down-regulation of cinnamoyl-CoA reductase in tomato (Solanum lycopersicum L.) induces dramatic changes in soluble phenolic pools. Journal of Experimental Botany, 57: 1399-1411.

Received: 02/03/2016

Accepted: 06/09/2016 